\title{
The influence of atmospheric circulation on the occurrence of dry and wet periods in Central Poland in 1954-2018
}

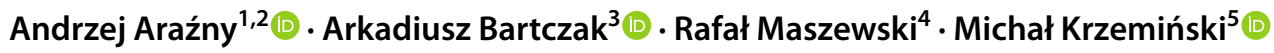

Received: 1 March 2021 / Accepted: 9 September 2021 / Published online: 24 September 2021

(c) The Author(s) 2021

\begin{abstract}
This work presents the influence of atmospheric circulation on the occurrence of dry and wet periods in the central Polish region of Kujawy. The material on which the authors relied encompassed monthly totals of precipitation obtained from 10 weather stations in the period 1954-2018. Both dry and wet periods have been identified on the basis of monthly values of the Standardised Precipitation Index (SPI). Additionally, the calendar of circulation types over Central Poland was used to determine the atmospheric circulation indices: western (W), southern (S) and cyclonicity (C). The analyses have indicated that the region concerned experiences low precipitation totals in comparison with the rest of Poland. According to the circulation indices W, S and C, for Central Poland, the air mass advection from the West prevails over that from the East. Moreover, a slightly more frequent inflow of air from the South than from the North has been observed. The frequency of anticyclonic situations is higher than that of the cyclonic types in this part of Europe. Drought spells occurred in the study area at a clear dominance of anticyclonic circulation, with the inflow of air mostly from the North and with increased westerly circulation. On the other hand, the occurrence of wet periods was mainly influenced by cyclonic circulation during the advection of the masses from the South and West. Dry and wet periods accounted for $28 \%$ and $27 \%$ of the study period, respectively.
\end{abstract}

\section{Introduction}

The observed changeability in the occurrence of dry and wet periods results from atmospheric circulation which tends to favour either continental or oceanic influences, thus shaping the climate both globally and locally (Twardosz et al. 2011). Atmospheric circulation responsible for precipitation variability in Poland or Europe is assessed with macro-scale indices (e.g. Hess and Brezowsky 1969, 1977; Hurrell 1996;

Andrzej Araźny

andy@umk.pl

1 Department of Meteorology and Climatology, Nicolaus Copernicus University, Toruń, Poland

2 Centre for Climate Change Research, Nicolaus Copernicus University, Toruń, Poland

3 Department of Environmental Resources and Geohazards, Institute of Geography and Spatial Organization Polish Academy of Sciences, Toruń, Poland

4 Marshal Office of Kujawsko-Pomorskie Voivodship, Toruń, Poland

5 Institute of Applied Mathematics, Faculty of Applied Physics and Mathematics, Gdańsk University of Technology, Gdańsk, Poland
Wibig 1999, 2001) or regional typologies (e.g. Niedźwiedź 1981; Przybylak and Maszewski 2009; Bartoszek 2017a). Moreover, Polish researchers often rely on the calendar of circulation types for southern Poland (Niedźwiedź 1981, 2017), which has been repeatedly applied to assess the influence of atmospheric circulation on precipitation in this part of the country (e.g. Niedźwiedź et al. 2009; Twardosz 2009, 2010; Twardosz and Niedźwiedź 2001; Twardosz et al. 2011). With the same method, Niedźwiedź (2013a) prepared the calendar of circulation types for Spitsbergen (the Arctic) later used for the assessment of the impact of atmospheric circulation on climate warming in that particular area (e.g. Araźny 2008, 2019; Araźny et al. 2018; Niedźwiedź 2013b; Isaksen et al. 2016; Łupikasza and Niedźwiedź 2019).

Circulation conditions can be generalised through indices that contain key information about the changes in intensity of zonal and meridional circulation over a study area (Kożuchowski 1993; Kutiel et al. 1996; Jacobeit et al. 2001; Tomingas 2002; Nowosad 2011; Bartoszek 2017b). For the area of Poland, one can distinguish indices put forward by, e.g., Lityński (1969), Ustrnul (1997) and Niedźwiedź (2000). Those by Niedźwiedź (2000) are a modified version of the method suggested by Murray and Lewis (1966). They were used to study the long-term variability of atmospheric 
circulation and to assess its impact on the temporal and spatial changeability of selected meteorological elements in Poland (e.g. Niedźwiedź 2000; Falarz 2007; Niedźwiedź et al. 2009) and in the Arctic (e.g. Araźny 2008; Niedźwiedź 2013b; Niedźwiedź and Łupikasza 2015).

In this study, the Authors determined the following indices of atmospheric circulation-western (W), southern (S) and cyclonicity $(\mathrm{C})$. These were calculated on the basis of the calendar of atmospheric circulation type by Maszewski (Przybylak and Maszewski 2009) over central Poland (i.e. the Bydgoszcz-Toruń region) using the methodology proposed by Niedźwiedź (2000).

Located in the central part of Europe, climate-wise, Poland is influenced by both the Atlantic Ocean and the Eurasian continent (Fig. 1). Central Poland lies in the zone of temperate, warm transitional climate, separating the maritime climate from the continental one. This area is often surrounded by air masses with different thermal and humidity properties, resulting in large weather fluctuations and the occurrence of various types of precipitation (Woś 2010; Twardosz et al. 2011). Central Poland has proved to be the most water-scarce area. It is unique because, on the one hand, it suffers from an unfavourable structure of the water balance featuring some of the lowest precipitation totals and unit runoffs in Poland (e.g. Łabędzki and Bąk 2004; Bartczak 2007; Brykała 2009; Woś 2010; Bartczak et al. 2013). On the other hand, the study area is predominantly agricultural, and as such, particularly vulnerable to extreme weather events.

The Authors applied the Standardised Precipitation Index (SPI) (McKee et al. 1993) to determine the occurrence of dry and wet periods. The SPI is widely used in research or operational activities in more than 70 countries (WMO 2012), approaching both fundamental studies and applications (i.e. agriculture, forestry, hydrology). Currently, it is possibly one of the most popular indices for estimating dry and wet periods, but mainly droughts (e.g. Lloyd-Hughes and Saunders 2002; Bordi et al. 2004; 2007; Livada and Assimakopoulos 2007; Zhang et al. 2009; Brázdil et al. 2013, 2016, 2018; Przybylak et al. 2020). In central Poland, the index helps to determine the occurrence and intensity of meteorological drought in various time scales (e.g. Bąk and

Fig. 1 Location of meteorological stations used in this study

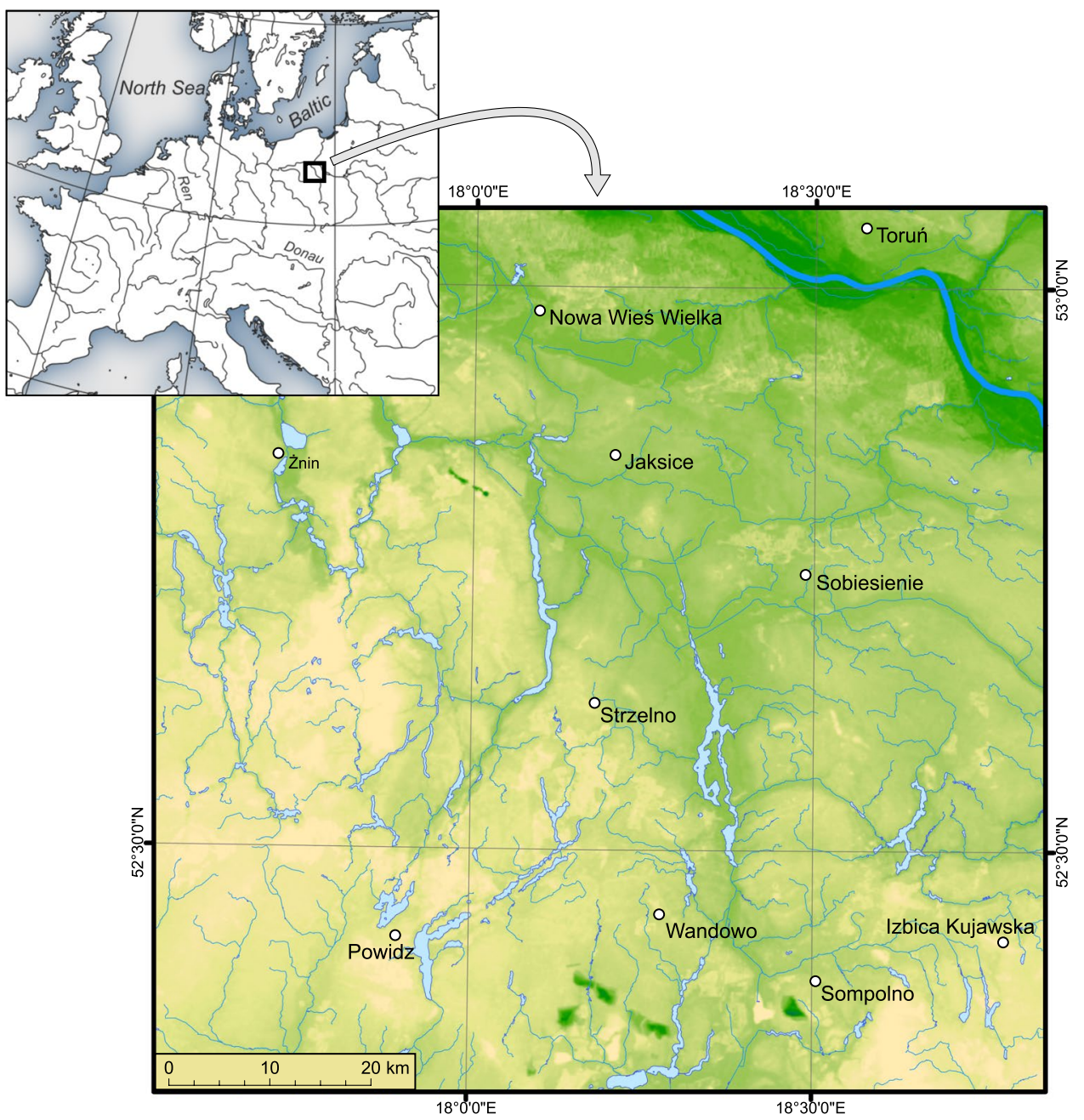


Łabędzki 2002; Łabędzki 2007, 2008; Łabędzki and Bąk 2004). It is the means used in many countries to monitor the risk of drought (IMGW 2020; National Drought Mitigation Center 2020).

The aim of this study was to detect dry and wet periods and link them with the occurrence of a specific type of atmospheric circulation in Central Poland in the years 1954-2018. For this purpose, three regional indices of atmospheric circulation, i.e. western circulation, southern circulation and the cyclonicity, were used. Moreover, temporal variability of atmospheric circulation over central Poland was presented.

\section{Area, data and analysis methods}

The study area is located in Central Poland in the eastern part of Kujawy. For the analysis of dry and wet periods, monthly totals of precipitation from 10 meteorological or precipitation stations in the years 1954-2018 were used (Table 1). Figure 1 shows the location of all the analysed stations. All the data come from the Institute of Meteorology and Water Management - National Research Institute (in Polish: Instytut Meteorologii i Gospodarki Wodnej - Państwowy Instytut Badawczy, hereafter: IMGW-PIB). Precipitation data were necessary to calculate the value of the Standardised Precipitation Index (SPI) and to identify dry and wet periods in the studied 65 years.

The types of air circulation and their frequency for Central Poland (in the Bydgoszcz-Torun region), also during dry and wet periods, were determined using the calendar of daily weather maps published by the German meteorological service (Deutscher Wetterdienst) for the period 1954-2018. The classification of types of circulation in the BydgoszczTorun region was prepared by Maszewski (Przybylak and Maszewski 2009), who developed a catalogue of the

Table 1 Characteristics of meteorological stations operating in Central Poland in the period 1954-2018

\begin{tabular}{lllll}
\hline No & Station & $\begin{array}{l}\text { Altitude [m } \\
\text { a.s.l. }\end{array}$ & Latitude & Longitude \\
\hline 1 & Toruń & 69 & $53^{\circ} 03^{\prime} \mathrm{N}$ & $18^{\circ} 36^{\prime} \mathrm{E}$ \\
2 & Nowa Wieś Wielka & 74 & $52^{\circ} 58^{\prime} \mathrm{N}$ & $18^{\circ} 06^{\prime} \mathrm{E}$ \\
3 & Jaksice & 85 & $52^{\circ} 51^{\prime} \mathrm{N}$ & $18^{\circ} 11^{\prime} \mathrm{E}$ \\
4 & Żnin & 82 & $52^{\circ} 50^{\prime} \mathrm{N}$ & $17^{\circ} 45^{\prime} \mathrm{E}$ \\
5 & Sobiesiernie & 90 & $52^{\circ} 45^{\prime} \mathrm{N}$ & $18^{\circ} 27^{\prime} \mathrm{E}$ \\
6 & Strzelno & 105 & $52^{\circ} 38^{\prime} \mathrm{N}$ & $18^{\circ} 10^{\prime} \mathrm{E}$ \\
7 & Wandowo & 105 & $52^{\circ} 26^{\prime} \mathrm{N}$ & $18^{\circ} 18^{\prime} \mathrm{E}$ \\
8 & Izbica Kujawska & 120 & $52^{\circ} 26^{\prime} \mathrm{N}$ & $18^{\circ} 46^{\prime} \mathrm{E}$ \\
9 & Powidz & 102 & $52^{\circ} 25^{\prime} \mathrm{N}$ & $17^{\circ} 55^{\prime} \mathrm{E}$ \\
10 & Sompolno & 96 & $52^{\circ} 23^{\prime} \mathrm{N}$ & $18^{\circ} 31^{\prime} \mathrm{E}$ \\
\hline
\end{tabular}

atmospheric circulation types using the classification scheme by Niedźwiedź (1981). The latter was first in Poland to construct a catalogue of circulation types for the upper Vistula basin. Niedźwiedź (1981) based his classification on the atmospheric circulation typology prepared by Lamb (1972) for the British Isles and introduced certain modifications concerning non-directional situations. Using weather maps for Europe, the direction of the air masses advection (e.g. $\mathrm{N}$ - northern, SE - south-eastern) and the type of a pressure system (a - anticyclonic situation, $\mathrm{c}$ - cyclonic situation) were determined. In addition to 16 synoptic situations with air advection, two more with no advection were identified: $\mathrm{Ca}$ - centre of high pressure and $\mathrm{Ka}$ - wedge or ridge of high pressure, and also two cyclonic types with varied advection: $\mathrm{Cc}-$ centre of low pressure and $\mathrm{Bc}-$ cyclonic trough. Therefore, the overall classification encompasses 20 types (ten anticyclonic, and ten cyclonic). Situations that were difficult to classify and pressure cols were coded " $x$ " (unclassified type) (Niedźwiedź 1981; Łupikasza and Niedźwiedź 2019; Niedźwiedź and Łupikasza 2019).

To maintain the same methodological procedure (the use of monthly totals of precipitation for the calculation of the SPI), the Authors determined monthly atmospheric circulation indices out of daily synoptic types relying on the number (frequency) of occurrence of circulation types. Their determination was based on the four indices $\mathrm{P}, \mathrm{M}, \mathrm{S}$ and $\mathrm{C}$ suggested by Murray and Lewis (1966) and used Lamb's (1972) classification of circulation types for the British Isles. These indices were later modified by Niedźwiedź (2000, 2001) who gave up the meridional index $M$ for the benefit of the index $\mathrm{S}$ and replaced the progression index $\mathrm{P}$ with the index W. For the sake of this study, based on the number of Maszewski's circulation types (Przybylak and Maszewski, 2009), three circulation indices: the western circulation index (W), the southern circulation index (S) and the cyclonicity index (C) were calculated with the formula suggested by Niedźwiedź $(2000,2001)$ and Niedźwiedź et al. (2009). It is possible to calculate the indices for individual months, seasons or a year by adding up weight points $(-2,-1$, $0,+1,+2$ ) ascribed to particular types of circulation. The $\mathrm{W}$ index determines the intensity of the westerly (positive values) or easterly (negative values) circulation. For individual days, depending on the direction of air mass advection, the following points were assigned: +2 for the $\mathrm{W}$ direction, +1 for the NW and SW direction, -2 for $\mathrm{E}$ and -1 for NE and SE. The remaining types of circulation were given the value of zero. The $\mathrm{S}$ index shows the intensity of the meridional (positive values) or northerly (negative values) circulation. For individual days, depending on the direction of air mass advection, the following points were assigned: +2 for the $\mathrm{S}$ direction, +1 for $\mathrm{SE}$ and $\mathrm{SW},-2$ for $\mathrm{N}$ and -1 for $\mathrm{NE}$ and NW (Niedźwiedź 2000, 2001; Niedźwiedź et al. 2009; Niedźwiedź and Łupikasza 2019). The cyclonicity index C 
indicates the degree of cyclonic (positive values) or anticyclonic (negative values) activity. The number of points given to certain circulation types is as follows: +2 for the situation $\mathrm{Cc}$ (centre of cyclone) and $\mathrm{Bc}$ (cyclonic trough), +1 for the other cyclonic types, and -2 for the Ca type (centre of anticyclone) and $\mathrm{Ka}$ (wedge of high pressure), -1 for other anticyclonic types (Niedźwiedź 2000, 2001, 2013a; Niedźwiedź et al. 2009; Przybylak and Maszewski 2009; Niedźwiedź and Łupikasza 2019). The obtained values of the $\mathrm{W}, \mathrm{S}$ and $\mathrm{C}$ circulation indices were grouped into 12 -month periods using the so-called moving sum windows and were later referred to as $\mathrm{W}-12, \mathrm{~S}-12$ and $\mathrm{C}-12$. They were used to calculate the relationship between the values of the discussed circulation indices and the intensity of dry and wet periods.

The study of the direction of changes in annual precipitation totals and atmospheric circulation indices (estimation and significance) was carried out using the non-parametric Mann-Kendall (MK) test (Hirsch et al. 1982). The null hypothesis of the $\mathrm{H} 0$ test assumes that the data come from a population of independent data and is evenly distributed. On the other hand, the HA hypothesis of the test assumes that the data follow a monotonic trend. The MK test statistic is calculated according to the formula:

$S=\sum_{k=1}^{n-1} \sum_{j=k+1}^{n} \operatorname{sgn}\left(x_{j}-x_{k}\right)$

with

$\operatorname{sgn}(\theta)=\left\{\begin{array}{cc}1 & \text { if } \theta>0 \\ 0 & \text { if } \theta=0 \\ -1 & \text { if } \theta<0\end{array}\right.$

If the data are distributed identically and independently, then the mean is 0 , and the variance for the $S$ statistic is defined by the formula:

$\sigma^{2}=\frac{1}{18}\left(n(n-1)(2 n+5)-\sum_{j=1}^{k} t_{j}\left(t_{j-1}-1\right)\left(2 t_{j}+5\right)\right)$

It can be assumed that the $S$ statistic takes the form of a standard normal distribution if the following $Z$ transformation is applied:

$Z=\left\{\begin{array}{c}\frac{S-1}{\sigma} \text { if } S>0 \\ 0 \text { if } S=0 \\ \frac{S+1}{\sigma} \text { if } S<0\end{array}\right.$

The significance of the MK test was assessed at the level of 0.05 .

Dry and wet periods were quantified with the SPI. The series of annual and monthly precipitation totals were normalised using the Box-Cox transformation (Box and Cox 1964, 1982). Such a procedure allowed the Authors to obtain a vector of normalised values. The Box-Cox transformation of the variable, indexed by the parameter $\lambda$, is given by the formula:

$u^{(\lambda)}=\left\{\begin{array}{ll}\frac{x^{\lambda}-1}{\lambda} & \lambda \neq 0 \\ \ln x & \lambda=0\end{array}\right.$ for $x>0$

Next, the transformed series were standardised with an aim to obtain the series with an average value $(\mu)=0$ and standard deviation $(\sigma)=1$. Finally, the calculated values were classified according to the scheme presented in the work of McKee et al. (1993). Negative SPI values below -1.0 indicate a moderate drought period, below -1.5 a severe drought period and below -2.0 an extreme drought period. Similarly, positive SPI values above +1.0 indicate the occurrence of a moderate wet period, above +1.5 a severe wet period and above +2.0 an extreme wet period.

The smoothing of the calculated SPIs and circulation indices was presented using a moving trend (Hellwig 1967). This method is especially useful for the analysis of long series that are characterised by irregular and numerous changes in the direction of trends. Series smoothing involves setting an arbitrary smoothing constant $k(k<n)$, and then estimating the structural parameters of the linear trend function on the basis of successive fragments of the series with a fixed length $k$. For the chronological series $y_{1}, y_{2}, \ldots, y_{n}$ and the smoothing constant $k$ the subsequent fragments of the series are:

$$
\begin{gathered}
y_{1}, \ldots, y_{k} \\
y_{2}, \ldots, y_{k+1} \\
y_{n-k+1}, \ldots, y_{n}
\end{gathered}
$$

Then, the structural parameters of the functions in each segment were estimated with the least squares method. The number of segments in a series is equal to $n-k+1$. The linear trend functions for each segment take the form:

$$
\begin{array}{ccc}
\hat{y}_{1}=a_{1}+b_{1 x} & \text { for } & 1 \leq t \leq k \\
\hat{y}_{2}=a_{2}+b_{2 x} & \text { for } & 2 \leq t \leq k+1 \\
\hat{y}_{n-k+1}=a_{n-k+1}+b_{n-k+1} x & \text { for } & n-k+1 \leq t \leq+1
\end{array}
$$

Finally, the arithmetic means of the theoretical values were calculated. The analysis was performed for the constant $k=10$ years.

The relationship between the SPIs-12 during dry/wet periods and the corresponding indices of a specific atmospheric circulation was expressed using Spearman's rank correlation coefficient, which is determined with the formula (Kot et al. 2011): 
$r_{s}=1-\frac{6 \sum_{i=1}^{n}\left(x_{i}^{*}-y_{i}^{*}\right)^{2}}{n\left(n^{2}-1\right)}$

Spearman's rank correlation coefficient assumes values in the range $[-1 ;+1]$. The statistical significance of the $r_{s}$ coefficient was verified by making the null hypothesis $\mathrm{H} 0$ : $\rho=0$, while the alternative hypothesis is HA: $\rho \neq 0$.

\section{Results}

\subsection{Precipitation}

The annual precipitation averaged in Kujawy (based on ten stations) was $524 \mathrm{~mm}$ in the years 1954-2018. In the study area, the average totals vary depending on local conditioning, e.g. the rain shadow of lakeland uplands. The annual precipitation for individual years differs from the average sum calculated for a multi-year period, sometimes by over $150 \%$. The highest average annual precipitation (approx. $550 \mathrm{~mm}$ ) was recorded in Strzelno and Nowa Wieś Wielka, while the lowest readings $(<480 \mathrm{~mm})$ appeared in the central and southern part of the region, especially in the vicinity of the village of Wandowo (Table 2, Fig. 2a). Within the analysed period, 1989 had the lowest average annual precipitation (Fig. 2b), whereas 2010 figured as the most precipitation-abundant year in Kujawy (Fig. 2c). It was then that the average annual precipitation in this area reached $788 \mathrm{~mm}$, which was $150 \%$ of the 65 -year mean (Fig. 2). 2010 saw catastrophic river swelling events leading to numerous floods or inundations not only in the study area but also throughout Poland. The lowest yearto-year variability in precipitation (expressed in the values of standard deviation) was in Wandowo, while the highest in Strzelno (Table 2). As much as the multi-year pattern

Table 2 Statistical characteristics of precipitation in Central Poland in 1954-2018

\begin{tabular}{|c|c|c|c|c|c|c|}
\hline No & Station & Mean $[\mathrm{mm}]$ & Maximum [mm] (year) & Minimum [mm] (year) & $\begin{array}{l}\text { Standard } \\
\text { deviation }\end{array}$ & $p$-value of MK test \\
\hline 1 & Toruń & 536.3 & $843.3(1980)$ & 310.4 (1989) & 112.5 & 0.4053 \\
\hline 2 & Nowa Wieś Wielka & 549.0 & $805.0(1980)$ & $252.0(1989)$ & 120.4 & 0.7298 \\
\hline 3 & Jaksice & 503.6 & $720.3(2010)$ & 237.6 (1989) & 103.7 & 0.2599 \\
\hline 4 & Żnin & 524.1 & 795.1 (1967) & $278.0(1989)$ & 115.9 & 0.2672 \\
\hline 5 & Sobiesiernie & 506.9 & $826.8(2010)$ & 291.7 (1989) & 106.8 & 0.5522 \\
\hline 6 & Strzelno & 550.1 & $816.9(1980)$ & 246.6 (1989) & 123.7 & 0.9999 \\
\hline 7 & Wandowo & 477.4 & $754.9(2010)$ & 235.9 (1989) & 98.8 & 0.7341 \\
\hline 8 & Izbica Kujawska & 538.9 & $817.6(2010)$ & $309.6(2011)$ & 105.6 & 0.6506 \\
\hline 9 & Powidz & 539.4 & $841.1(2010)$ & 293.8 (1989) & 109.5 & 0.9819 \\
\hline 10 & Sompolno & 515.7 & $847.6(2010)$ & 302.7 (1989) & 100.5 & 0.5372 \\
\hline
\end{tabular}

Source: Own calculation based on IMGW data
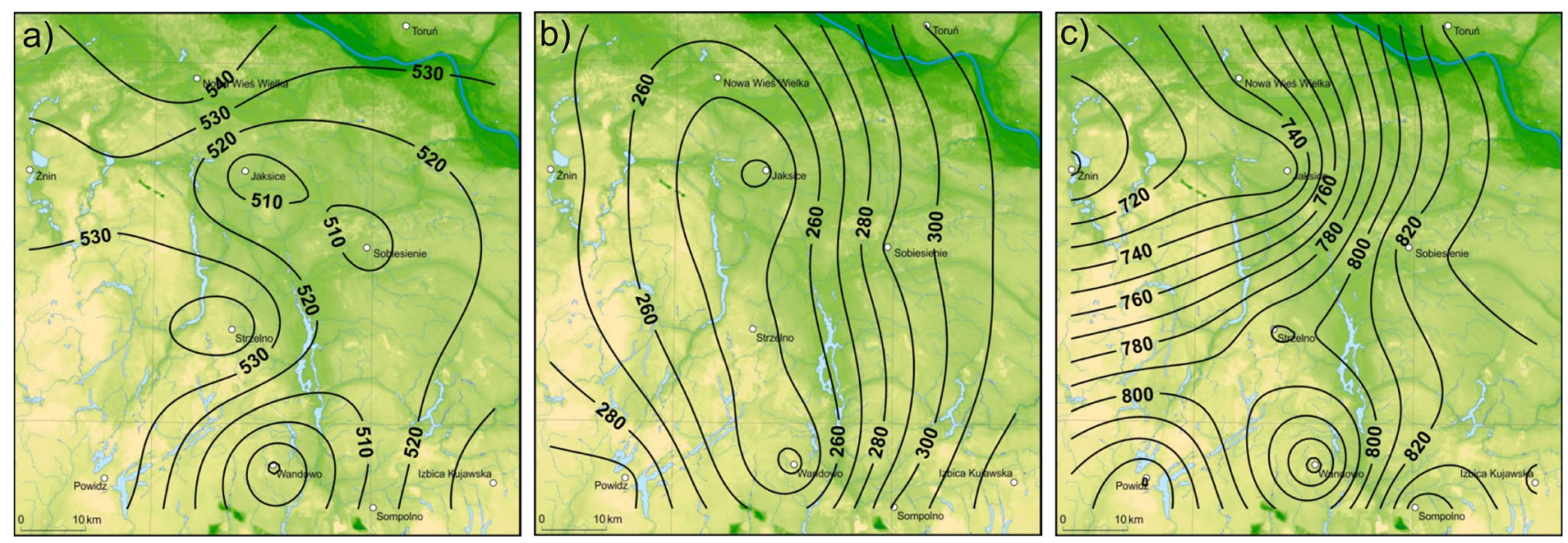

Fig. 2 Spatial distribution of mean annual precipitation totals. a In 1989 - the lowest totals. b In 2010 - the highest totals. c In the study area in 1954-2018 
of precipitation exhibits high year-to-year variability, the entire studied period is characterised by a slight, statistically insignificant, upwards trend $(2 \mathrm{~mm} / 10$ years $)$ in the mean total of precipitation (based on ten stations). In the analysed timespan, the tendencies of average annual totals at individual stations range from $-5 \mathrm{~mm} / 10$ years (Izbica Kujawska) to $7 \mathrm{~mm} / 10$ years (Toruń and Jaksice).

The annual course of precipitation in Kujawy shows the minimum at the turn of winters and springs. The lowest average precipitation in the whole area was in February $(26.3 \mathrm{~mm})$. Also in February, the average precipitation was characterised by small spatial differentiation ranging from $20.7 \mathrm{~mm}$ in Wandowo to $30.3 \mathrm{~mm}$ in Powidz. In the analysed region, the highest average precipitation happened in July $(82.8 \mathrm{~mm})$ with the spatial differentiation ranging from $78.6 \mathrm{~mm}$ in Powidz to $88.4 \mathrm{~mm}$ in Toruń.

If one compares the multi-year and monthly precipitation totals, the difference between them is significantly more pronounced. At 6 out of 10 stations, there are months with an extreme deficit of precipitation with no or $<1 \mathrm{~mm}$ precipitation. On the other hand, the largest monthly totals of precipitation, recorded in the summer months, in some years may even exceed four times those calculated for a multi-year period. For instance, in Torun in June 1980, the precipitation total was $298.6 \mathrm{~mm}$ (long-term mean total $65.4 \mathrm{~mm}$ ), and in Nowa Wieś Wielka $294.1 \mathrm{~mm}$ (mean total also $65.4 \mathrm{~mm}$ ).
Farmers particularly value the information about the amount of precipitation during the growing season (April to September). For this period of the year, the total precipitation averaged from $308 \mathrm{~mm}$ in Wandowo to $345 \mathrm{~mm}$ around Toruń. In the entire study area, the share of total precipitation during the growing season in the annual total precipitation exceeds $59 \%$ and is the highest in the vicinity of Toruń and Wandowo (>64\%).

\subsection{Standardised Precipitation Index}

Based on the precipitation data, the annual SPIs were calculated for all the stations, thus enabling the Authors to identify dry and wet periods within 1954-2018. Figure 3 shows the year-to-year SPI values at selected stations with the highest, average and the lowest multi-year precipitation in the study area, i.e. in Strzelno, Toruń and Wandowo, respectively. During the analysed period, at most of the studied stations, we observed two years (1980 and 2010) that were extremely wet (SPI > 2), and two (1982 and 1989) classified as extremely dry $(\mathrm{SPI}<2)$.

Calculated on the basis of normalised and standardised 12-month precipitation totals (Tables 3 and 4), dry and wet periods were identified. The course of the SPI- 12 for all the stations in individual months is presented in Fig. 4.

In the study area in the years 1954-2018, the total number of dry periods ranged from 11 (Strzelno) to 16 (Powidz
Fig. 3 The values of the annual Standardised Precipitation Index (SPI) at selected weather stations: Strzelno (the highest mean multi-year precipitation total), Toruń (mean multiyear precipitation total) and Wandowo (the lowest mean multi-year precipitation total) in 1954-2018. Note: the bars represent Standardised Precipitation Indices (SPIs), the line represents the moving trend ( indow $=10$ ); the bar colours represent the intensity of the SPI: black- extremely wet, dark blue - severely wet, blue moderately wet, green - normal, yellow - moderate drought, orange - severe drought, red extreme drought
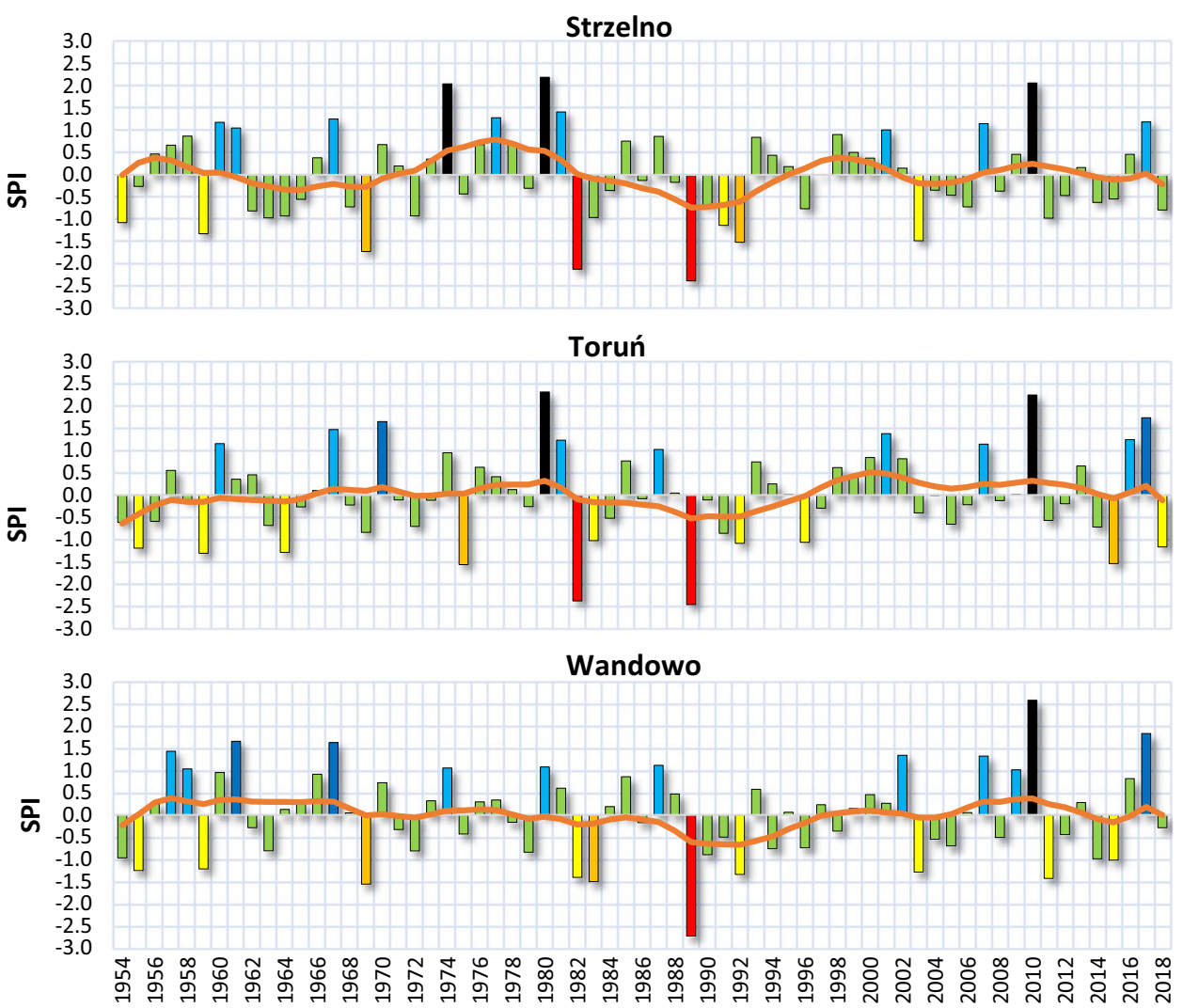
Table 3 Characteristics of dry periods in the research area in 1954-2018

\begin{tabular}{llllll}
\hline No & Station & $\begin{array}{l}\text { Total no. of } \\
\text { dry periods }\end{array}$ & $\begin{array}{l}\text { Total no. } \\
\text { of months }\end{array}$ & $\begin{array}{l}\text { Maximum no. of months } \\
\text { during one dry period }\end{array}$ & $\begin{array}{l}\text { Minimum no. of } \\
\text { months during one dry } \\
\text { period }\end{array}$ \\
\hline 1 & Toruń & 14 & 233 & 51 & 2 \\
2 & Nowa Wieś Wielka & 12 & 211 & 53 & 2 \\
3 & Jaksice & 13 & 227 & 52 & 2 \\
4 & Żnin & 13 & 240 & 48 & 2 \\
5 & Sobiesiernie & 14 & 187 & 34 & 3 \\
6 & Strzelno & 11 & 211 & 50 & 2 \\
7 & Wandowo & 15 & 252 & 50 & 2 \\
8 & Izbica Kujawska & 13 & 192 & 29 & 2 \\
9 & Powidz & 16 & 241 & 52 & 1 \\
10 & Sompolno & 16 & 184 & 25 & 2 \\
\hline
\end{tabular}

\begin{tabular}{llllll}
\hline No & Station & $\begin{array}{l}\text { Total no. of } \\
\text { wet periods }\end{array}$ & $\begin{array}{l}\text { Total no. } \\
\text { of months }\end{array}$ & $\begin{array}{l}\text { Maximum no. of months } \\
\text { during one wet period }\end{array}$ & $\begin{array}{l}\text { Minimum no. of } \\
\text { months during one wet } \\
\text { period }\end{array}$ \\
\hline 1 & Toruń & 14 & 213 & 32 & 4 \\
2 & Nowa Wieś Wielka & 15 & 220 & 26 & 4 \\
3 & Jaksice & 15 & 202 & 24 & 5 \\
4 & Żnin & 14 & 223 & 36 & 4 \\
5 & Sobiesiernie & 13 & 202 & 28 & 4 \\
6 & Strzelno & 14 & 218 & 25 & 7 \\
7 & Wandowo & 15 & 237 & 27 & 4 \\
8 & Izbica Kujawska & 16 & 235 & 35 & 7 \\
9 & Powidz & 13 & 193 & 26 & 3 \\
10 & Sompolno & 16 & 199 & 23 & 8 \\
\hline
\end{tabular}

Table 4 Characteristics of wet periods in the research area in 1954-2018

\subsection{Atmospheric circulation indices}

Over Central Poland, in the years 1954-2018, the advection of air from the west clearly prevailed over that from the east, and the inflow of air from the south was slightly more frequent than from the north. The frequency of anticyclonic situations was higher than that of cyclonic types (Table 5). In the analysed multi-annual period, all the indices exhibit high month-to-month (Fig. 5a) and year-to-year (Fig. 5b) variability.

The value of the $\mathrm{W}$ index ( $W=114$ for a year) informs that the western component dominated over the eastern one in the analysed period 1954-2018. A statistically significant growing trend of this indicator was found (Table 5, Fig. 5), indicating the dominance of the frequency of air inflow from the west. In the examined 65 years, the annual W index was only negative twice (1960 and 1996) (Fig. 5b). One should remember that this index is highly changeable from year to year. In the twenty-first century, positive deviations prevailed (predominance of westerly circulation). 
Fig. 4 Values of Standardised Precipitation Indices of monthly precipitation (SPI-12) at the analysed stations in 1954-2018
Table 5 Characteristics of the annual atmospheric circulation indices: western $(\mathrm{W})$, southern (S) and cyclonicity (C) in the study area in 1954-2018
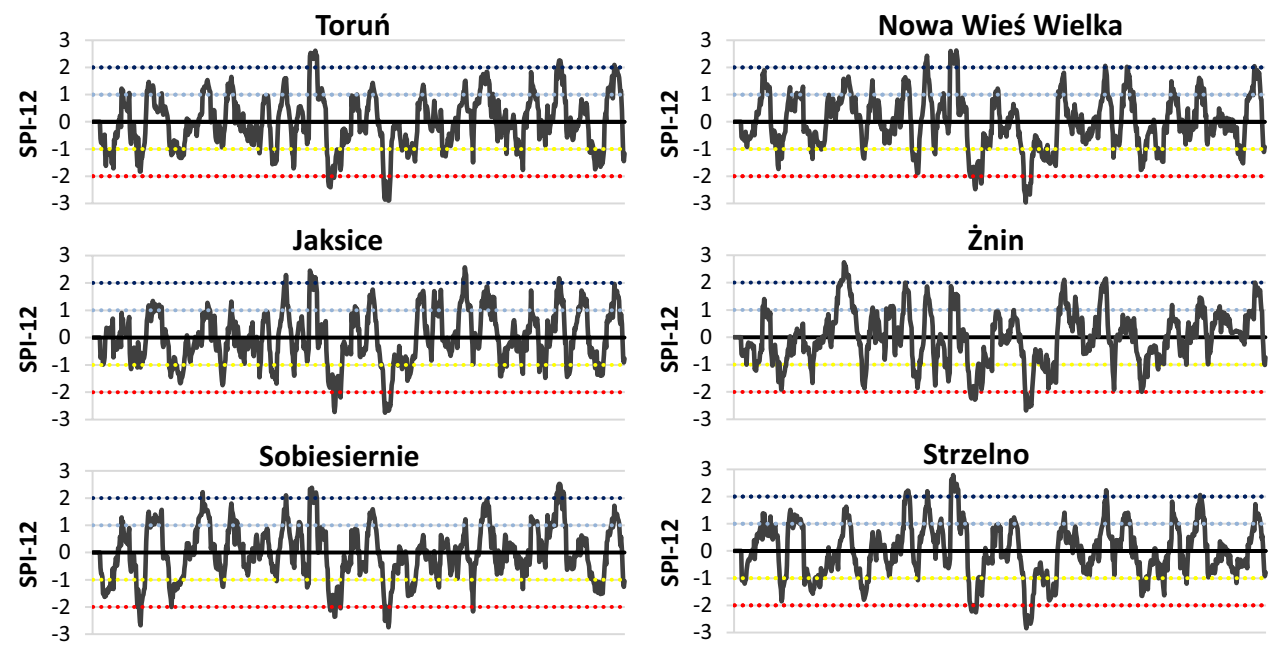

Wandowo

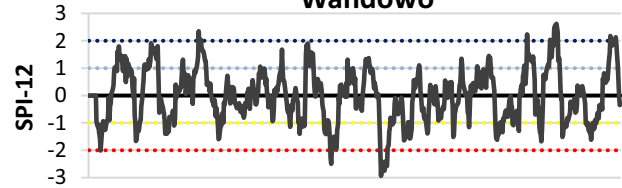

Powidz
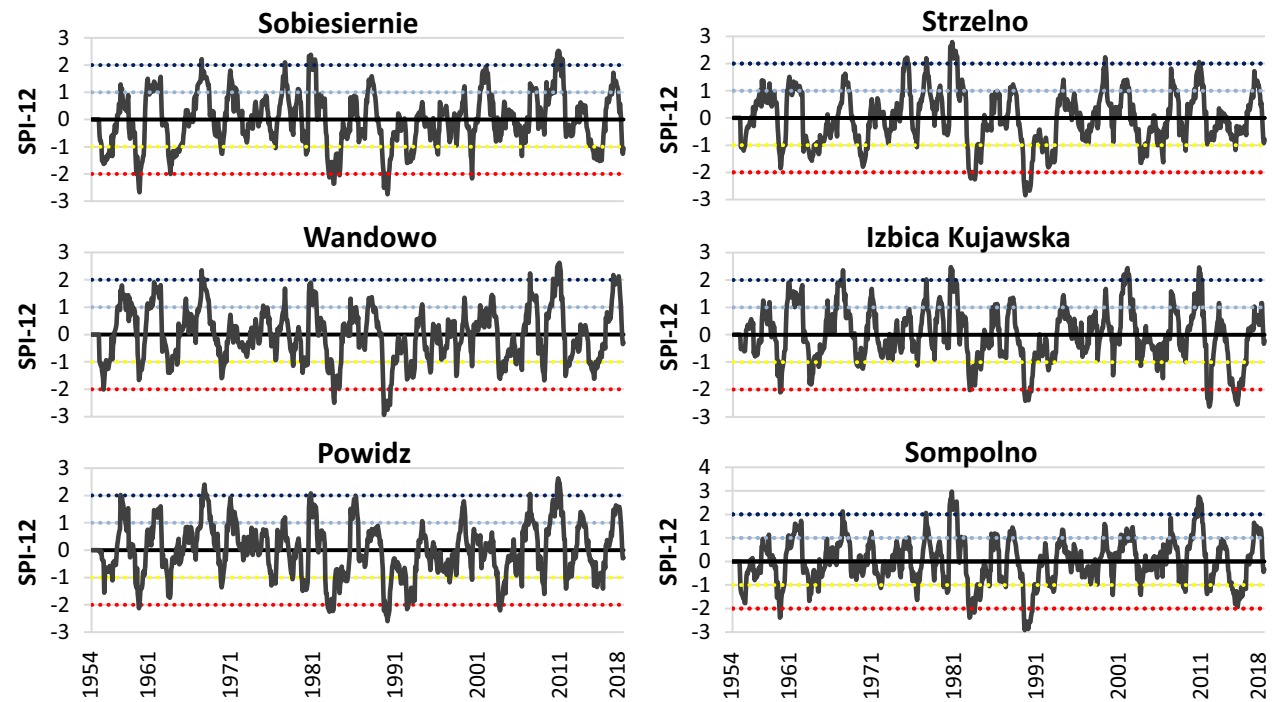

Izbica Kujawska

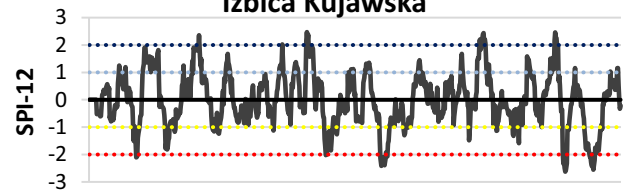

Sompolno

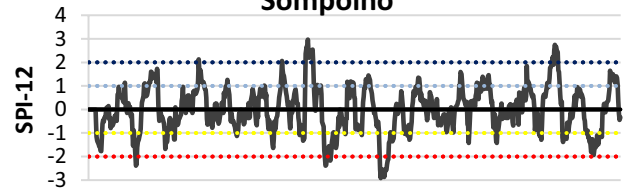

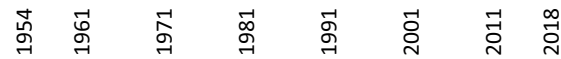

\begin{tabular}{lrllll}
\hline $\begin{array}{l}\text { Circulation } \\
\text { index }\end{array}$ & Mean & Maximum (year) & Minimum (year) & $\begin{array}{l}p \text {-value for Mann- } \\
\text { Kendall test }\end{array}$ & $\begin{array}{l}\text { Standard } \\
\text { deviation }\end{array}$ \\
\hline W & 114.4 & $227(1983)$ & $-15(1960)$ & $\mathbf{0 . 0 0 8 2}$ & 54.9 \\
S & 0.5 & $104(2014)$ & $-53(1997)$ & 0.7945 & 30.3 \\
C & -24.4 & $92(1980)$ & $-169(1959)$ & 0.8740 & 58.2 \\
\hline
\end{tabular}

Bold value denotes statistical significance at the $p<0.05$ level

In the average multi-annual course of the $\mathrm{W}$ index, the zonal form of circulation is characteristic, mostly from October to January (in December this index rises to 18.6). In the remaining months, this flow weakens, and only in May does it reach a negative value $(W=-1.8)$. The most intense westerly circulation was recorded in January $1983(W=52)$. On the other hand, the highest intensity of the easterly circulation was in March 1964 ( $W=-35$ ) (Fig. 5a).

In the analysed period, the $\mathrm{S}$ index was characterised by the lowest year-to-year variability. Its long-term mean value is 0.5 , which indicates a $50-50 \%$ share in the frequency of air inflow from the south and north. The trend of this index in the analysed period is not significant. Since the second decade of the twenty-first century, the intensity of the meridional circulation was increasing over central Poland (Fig. 5), and its maximum (104) occurred in 2014 (Fig. 5b).
The annual course of the $\mathrm{S}$ index, in 1954-2018, from October to March, indicates a dominance of the southern component over central Poland, with the highest intensity in November $(S=8.6)$. For the remaining 6 months, the opposite is observed, with the maximum in June and July ( $S=$ approx. -9$)$. The highest intensity of the meridional circulation was recorded in October $1976(S=40)$, while the strongest northern circulation occurred in September 1959 $(S=-30)$.

The $\mathrm{C}$ index informs about the average prevalence of high-pressure systems over Central Poland over a multi-year period ( $C=-24$ for a year). Similarly to the $\mathrm{W}$ index, it is also characterised by considerable volatility. The trend of the index in the analysed period is not significant (Table 5). In the long-term course, two periods can be distinguished: (a) from the mid-1950s to the beginning of the 1990s, when 
Fig. 5 The course of monthly (a) and annual (b) values of circulation indices $(\mathrm{W}, \mathrm{S}$ and $\mathrm{C})$ in the study area in 1954-2018; Note: $\mathrm{R}^{2}$ - coefficient of determination, straight and curved line respectively: moving (window $=10)$ and rectilinear trend a)

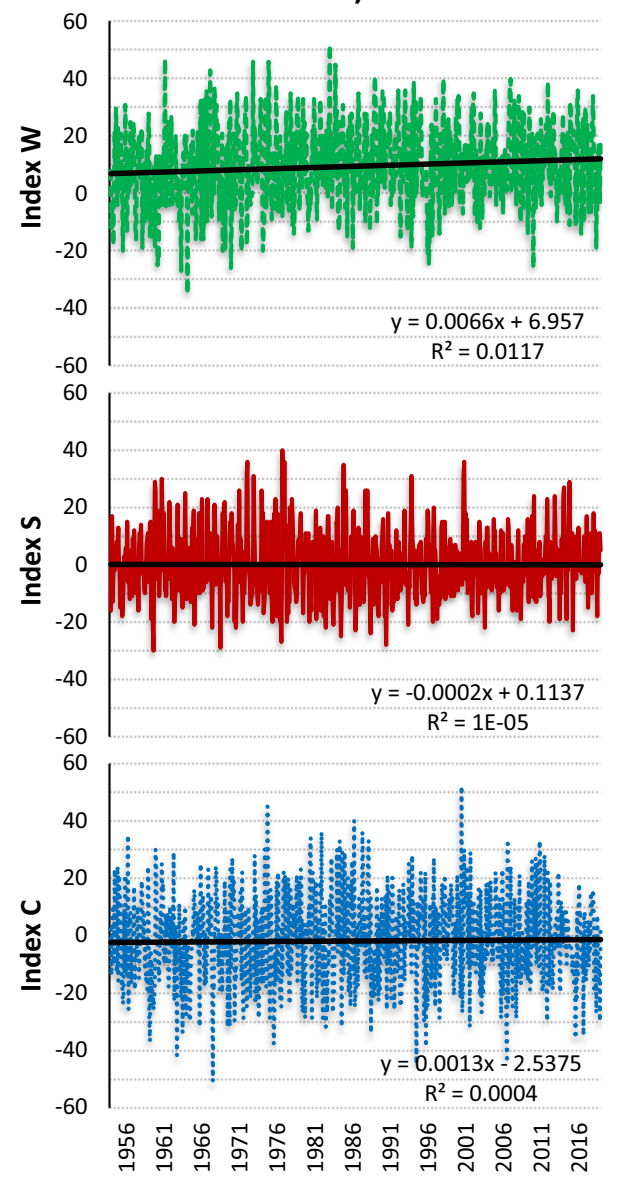

b)
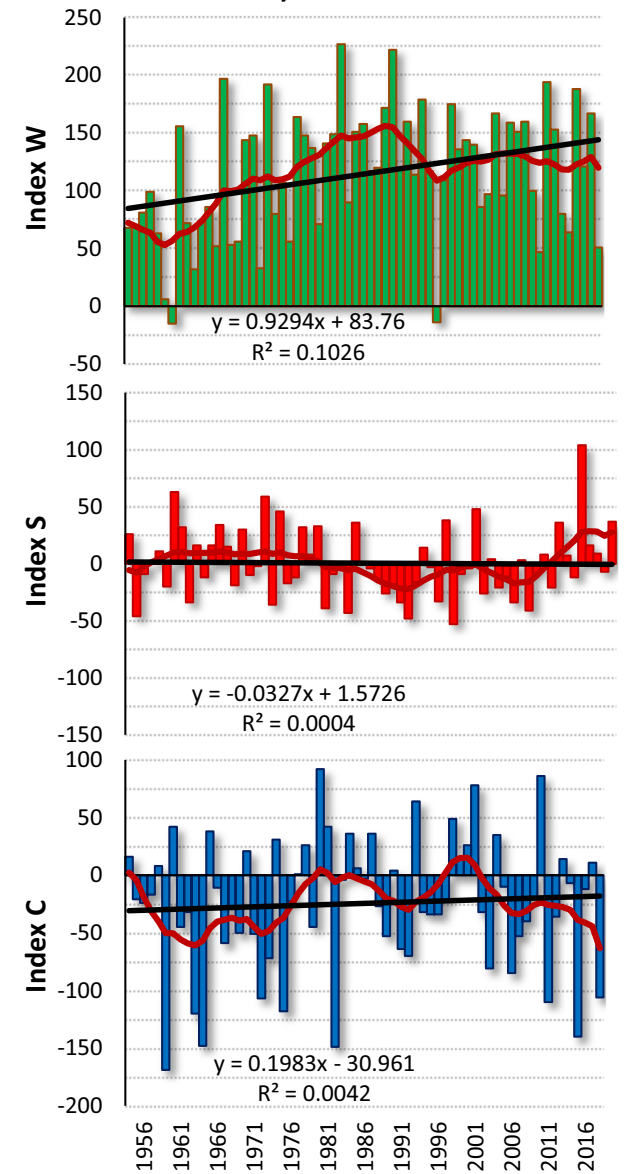

the frequency of low-pressure systems increased, and (b) from the end of the twentieth century to 2018, with a clear predominance of anticyclonic systems (Fig. 5).

In the annual course of the $\mathrm{C}$ index, in the studied 65 years, in the months from November to April, the predominance of cyclonic forms was visible, with the highest intensity in December $(C=4.1)$. In the remainder of the year, high-pressure forms prevailed over low-pressure ones, and the $\mathrm{S}$ index in its average annual course decreased to - 10 (in August). The strongest low-pressure activity was recorded in July $2000(C=52)$, while the strongest anticyclonic circulation occurred in July $1967(C=-51)$.

\subsection{Atmospheric circulation indices (W-12, C-12 and S-12) and their relation to SPI-12}

\subsubsection{Dry periods}

Figure 6 shows the average conditioning of the atmospheric circulation during dry periods. The occurrence of these periods was associated with negative averaged values $(-53.1)$ of the C-12 index in the study area (mean for 10 stations). The values of the index indicate that dry periods predominantly occur in the presence of the anticyclonic circulation (Fig. 6c). They were also recorded, in the entire study area, during the northern circulation (the average value of S-12 was - 7.6) (Fig. 6b). On the other hand, the mean value of W-12 was 118.5 for the dry periods (Fig. 6a). Positive values of this index inform about the influence of the western circulation in periods with scarce precipitation.

During dry periods, the results of the relationship between the SPI-12 and the C-12 circulation index expressed by the correlation coefficient $r_{s}$ indicate a high degree of convergence in their course. When dry periods begin, the values of the SPI-12 decrease, and so do those of the C-12 index. The reverse is also true: when dry periods end, both the SPI12 and C-12 values go up. This relationship is exemplified by the station in Torun (Fig. 7). Hence, the occurrence and duration of dry periods are heavily influenced by anticyclonic systems (Table 6). However, we cannot say that the incidence of a dry period is related to any specific values of the C-12 index.

For four out of ten analysed stations, the correlation coefficient $r_{s}$ between the SPI-12 and the S-12 circulation index is statistically significant (but its values are not high). This means that along with a decrease in the 

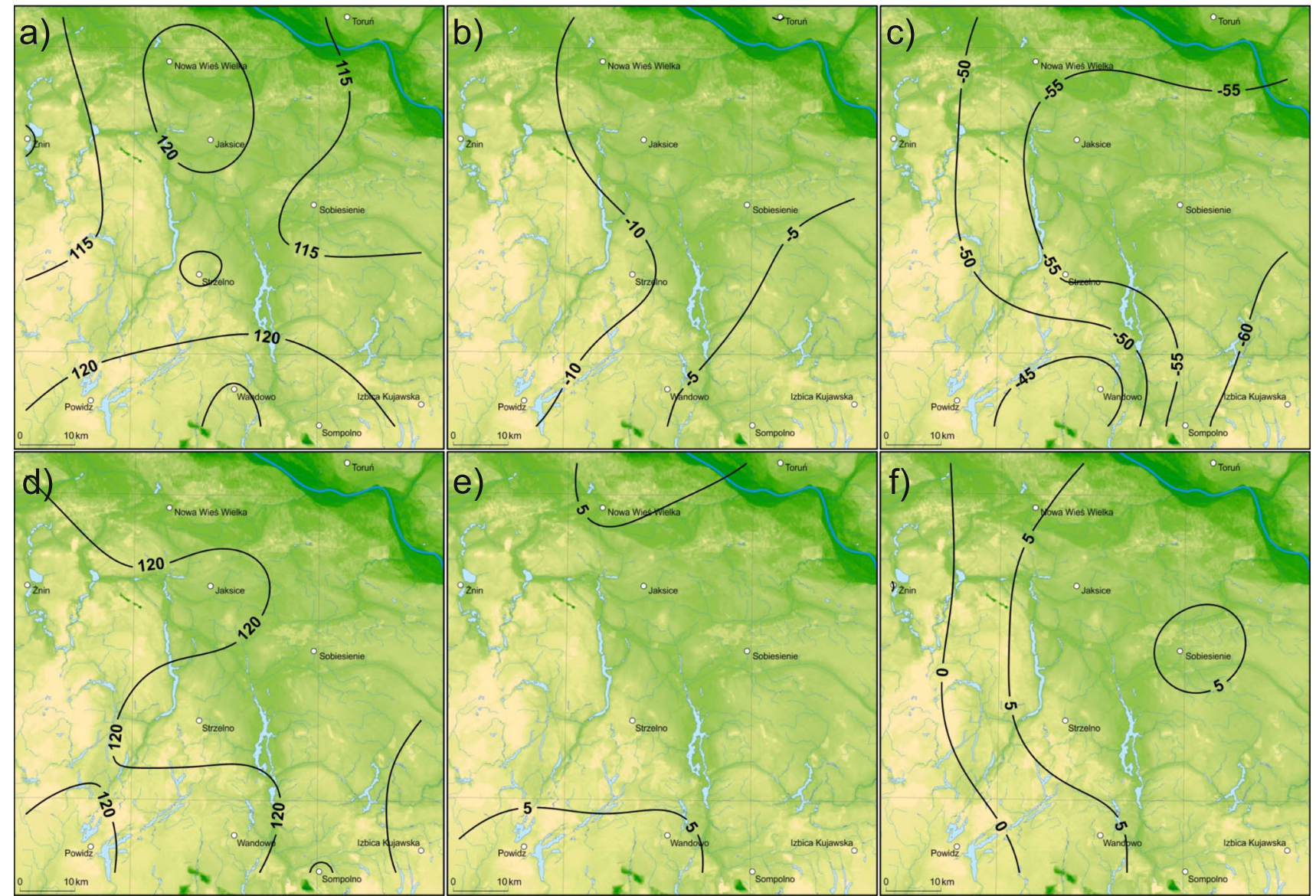

Fig. 6 Spatial distribution of mean values of atmospheric circulation indices: a W-12, b S-12 and c C-12 in dry periods (SPI-12 $\leq-1.0)$ and d W-12, e S-12 and $\mathbf{f}$ C-12 in wet periods (SPI-12 $\geq 1.0$ ) in the study area in 1954-2018

Fig. 7 The course of monthly indices of atmospheric circulation (W-12, S-12 and C-12) and the SPI-12 in Torun in 1954-2018

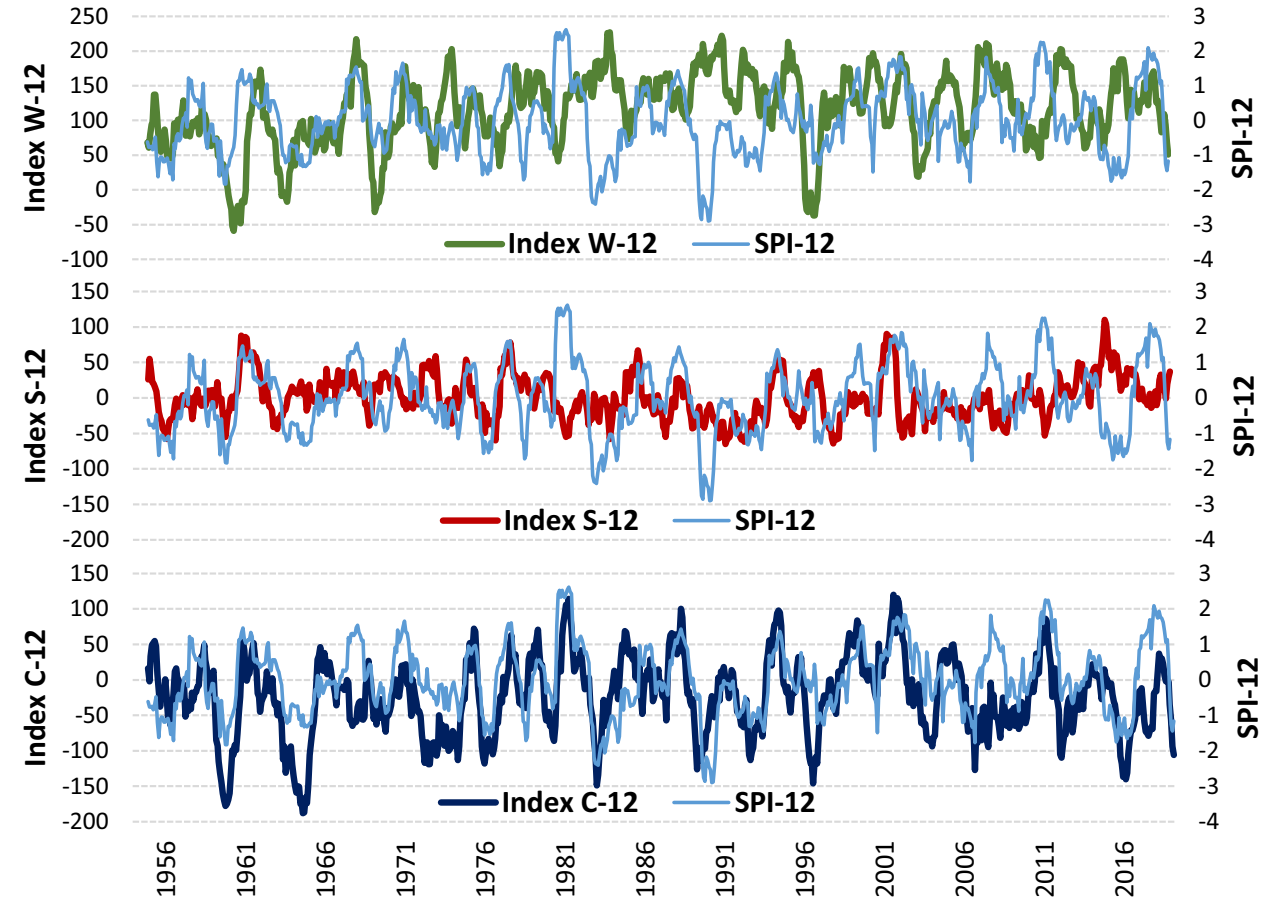


Table 6 Values of Spearman's correlation coefficients between atmospheric circulation indices (W-12, S-12 and C-12) and the SPI-12 during dry and wet periods in Central Poland in 1954-2018

\begin{tabular}{|c|c|c|c|c|c|c|}
\hline \multirow[t]{2}{*}{ Station } & \multicolumn{2}{|c|}{ SPI-12 / W-12 } & \multicolumn{2}{|l|}{ SPI-12 / S-12 } & \multicolumn{2}{|c|}{ SPI-12 / C-12 } \\
\hline & $\begin{array}{l}\text { Spearman's } \\
\text { correlation }\end{array}$ & $p$-value & $\begin{array}{l}\text { Spearman's } \\
\text { correlation }\end{array}$ & $p$-value & $\begin{array}{l}\text { Spearman's } \\
\text { correlation }\end{array}$ & $p$-value \\
\hline \multicolumn{7}{|l|}{ Dry periods } \\
\hline Toruń & -0.04 & 0.5255 & -0.12 & 0.0798 & 0.54 & $<0.0001$ \\
\hline Nowa Wieś Wielka & -0.27 & 0.0001 & 0.33 & $<0.0001$ & 0.30 & $<0.0001$ \\
\hline Jaksice & -0.21 & 0.0014 & 0.17 & 0.0094 & 0.41 & $<0.0001$ \\
\hline Żnin & -0.25 & 0.0001 & 0.18 & 0.0043 & 0.35 & $<0.0001$ \\
\hline Sobiesiernie & -0.11 & 0.1186 & 0.22 & 0.0030 & 0.36 & $<0.0001$ \\
\hline Strzelno & -0.08 & 0.2385 & 0.14 & 0.0503 & 0.29 & $<0.0001$ \\
\hline Wandowo & -0.12 & 0.0675 & 0.12 & 0.0544 & $\mathbf{0 . 3 1}$ & $<0.0001$ \\
\hline Izbica Kujawska & -0.20 & 0.0064 & -0.13 & 0.0691 & 0.29 & $<0.0001$ \\
\hline Powidz & -0.06 & 0.3454 & 0.09 & 0.1447 & 0.47 & $<0.0001$ \\
\hline Sompolno & -0.27 & 0.0002 & 0.13 & 0.0790 & 0.21 & 0.0038 \\
\hline \multicolumn{7}{|l|}{ Wet periods } \\
\hline Toruń & -0.09 & 0.1679 & -0.06 & 0.4140 & $\mathbf{0 . 4 3}$ & $<0.0001$ \\
\hline Nowa Wieś Wielka & -0.07 & 0.2844 & -0.06 & 0.3920 & 0.44 & $<0.0001$ \\
\hline Jaksice & -0.16 & 0.0259 & -0.12 & 0.0902 & 0.58 & $<0.0001$ \\
\hline Żnin & 0.08 & 0.2172 & 0.03 & 0.6759 & 0.42 & $<0.0001$ \\
\hline Sobiesiernie & -0.04 & 0.5815 & -0.07 & 0.3248 & 0.42 & $<0.0001$ \\
\hline Strzelno & -0.14 & 0.0402 & -0.03 & 0.6907 & 0.49 & $<0.0001$ \\
\hline Wandowo & -0.01 & 0.8263 & 0.05 & 0.4321 & 0.09 & 0.1637 \\
\hline Izbica Kujawska & -0.10 & 0.1464 & 0.02 & 0.7770 & 0.39 & $<0.0001$ \\
\hline Powidz & 0.02 & 0.7961 & -0.16 & 0.0297 & 0.27 & 0.0001 \\
\hline Sompolno & -0.22 & 0.0020 & -0.07 & 0.3469 & 0.43 & $<0.0001$ \\
\hline
\end{tabular}

Bold values denote statistical significance at the $p<0.05$ level value of the SPI-12, the values of the S-12 circulation index also go down. This, in turn, would indicate that during dry periods air flows from the north. However, a detailed analysis of dry periods and the S-12 atmospheric circulation indices corresponding to them shows that this relationship does not apply to all dry periods within 1954-2018. Therefore, the explanation of such a discrepancy in the obtained results may be purely statistical.

Investigating the relationship between dry periods of various lengths arranged in one series causes that they enter the analysis with different weights. One long dry period in which there is a strong relationship between the parameters tested can inflate the value of the studied correlation coefficient $r_{\mathrm{s}}$ for all combined periods. A similar situation occurs in the relationship between the SPIs-12 and the W-12 circulation indices (Table 6 ). At $50 \%$ of the analysed weather stations, a significant relationship was obtained, but also at relatively low values of the $r_{s}$ coefficient. Such a relation means that during dry periods there is a marked reduction in the inflow of air masses from the west.

\subsubsection{Wet periods}

Figure $6 \mathrm{~d}-\mathrm{f}$ shows the mean values of three standardised indices of atmospheric circulation during wet periods over central Poland in the years 1954-2018. Excessive precipitation in the analysed area resulted from increased cyclonic circulation (C-12). Its average value for the entire study area (based on 10 stations) during wet periods was 4.5 (Fig. 6f). The atmospheric circulation from the west $(\mathrm{W}-12=120.4)$ (Fig. 6d) and the meridional one (S-12=6.1) (Fig. 6e) was also responsible for the occurrence of wet periods. The three indicators show differences in their spatial distribution, which is caused, among others, by the landform, the rain shadow of the lakeland uplands and the type of land cover (Fig. 6).

During wet periods, the relationship with the $\mathrm{C}-12$ circulation index (cyclonic) expressed by the correlation coefficient $r_{s}$ is statistically significant for virtually all the stations. This means that in wet periods when the SPIs-12 take positive and simultaneously higher values, the values of the $\mathrm{C}$ index also increase. This relationship is not significant only 
for one station (Wandowo), and it is difficult to tell the reason for the low correlation coefficient there. The relationship between SPI-12 and the S-12 and W-12 circulation indices in most cases is not significant, which might indicate a variable inflow of air masses represented by the $\mathrm{S}-12$ and $\mathrm{W}-12$ circulation indicators during the wet period.

\section{Discussion and summary}

Precipitation is a highly variable element both in time and space. Low stability of precipitation totals is characteristic of Central Poland and is one of the key features of the climate in this part of Europe (e.g. Wibig 1999, 2009; Woś 2010; Wibig and Piotrowski 2018; Pińskwar et al. 2019; Szwed 2019; Ziernicka-Wojtaszek and Kopcińska 2020).

The area of Kujawy experiences some of the lowest precipitation totals in Poland. It was already back in the 1950s when Lambor (1954) indicated regions of the country that were most vulnerable to the process of turning into a steppe. These included Kujawy, Greater Poland (Wielkopolska) and parts of Mazovia, as those that are exposed to water scarcity particularly from May to September. Also, Kowalczak et al. (1997), based on the analysis of the climatic water balance (including potential evaporation and precipitation total) and the frequency of the lowest levels of the first waterbearing horizon, indicated the Greater Poland Lowland and the Greater Poland Lakeland as the areas most at risk of drought. Within the study area, low totals of precipitation were reported by Wójcik and Marciniak (1993), Łabędzki (2008), Woś (2010) and others. In the period 1951-1980, average annual precipitation totals below $500 \mathrm{~mm}$ did not occur throughout the entire Kujawy but happened locally in a "spot" manner. Within the study area, the central part of the catchment near Wandowo is an example of such a "spot". According to Wójcik and Marciniak (1993), such low mean annual totals can be down to a rather poorly diversified relief and the impact of the rain shadow of the lake uplands. The lowest recorded yearly totals of precipitation in Poland for the period 1951-2000 are <300 mm (Woś, 2010). The greatest concentration of precipitation minima is in Greater Poland, Kujawy and the northern part of Mazovia. For example, the minimum in Czernikowo and Unisław (Kujawy) stood at $210 \mathrm{~mm}$ and $250 \mathrm{~mm}$, respectively. Our research confirmed that the studied area has one of the lowest precipitation totals in the country. Water scarcity in central Poland is currently the key obstacle to more intensive development of agriculture in this area.

Our analyses have shown that in the course of many years, the trends of annual precipitation totals in Central Poland are not statistically significant. The results of our calculations find their confirmation, among others, in the study by Żmudzka (2002), who, having analysed the trends of precipitation at 50 weather stations in Poland in the second half of the twentieth century, stated that annual precipitation totals presented a statistically insignificant growing trend. Wibig (2009) also confirmed that precipitation in Poland did not change significantly in the second half of the twentieth century. For most of Poland, Czarnecka and NidzgorskaLencewicz (2012) reported a slight tendency to increase precipitation in spring and autumn with a simultaneously decreasing share of summer precipitation in the annual total. However, the pluvial regime in Poland did change in the second half of the twentieth century (1951-2000). According to Degirmendžić et al. (2004), the share of summer precipitation totals (June-August) in the annual sum decreased, which makes the main features of the continental climate less exposed. Based on the latest data from 1951-2013, Szwed (2019) reported that the annual precipitation in Poland had slightly increased. The trends and directions of the changes for individual weather stations are small and varied. Although in most of the country we do not observe a statistically significant trend in changes in precipitation (e.g. in the analysed Kujawy region), in its northern edges, a significant growing trend is visible. Szwed (2019) points at an increase in the share of precipitation in the winter months, while the share of summer precipitation is not changing, if not decreasing. Likewise, the newest climate forecasts, including research by the IPCC (2013), indicate that, in Central Europe, one should expect an increase in precipitation in winter and a decrease in summer. The results of research carried out in the neighbouring countries also signal rising trends in precipitation, e.g. in Germany (Hänsel et al. 2009), the Czech Republic (Beranová and Kyselý 2018) or in Ukraine (Boychenko et al. 2016).

In the late twentieth and the early twenty-first century, the nature of precipitation in this part of Europe also changed. In Poland, the incidence of heavy precipitation ( $>10 \mathrm{~mm} /$ day $)$ is higher (Pińskwar 2019), while rain of moderate intensity is consistently less frequent, and periods without precipitation are getting longer. All this is the result of the changing directions and routes of air masses moving over Europe. The increase in temperature in the Arctic is slowing down the "zonal circulation" inside the continent of Europe. Consequently, stationary high-pressure systems are being developed more and more often, preventing humid, rain-bringing air from the west into central Europe, and instead causing long-term precipitation-free periods. Changes in the precipitation pattern are part of the climate changes observed on a global scale. According to the IPCC (2013), the frequency and duration of heat waves, the frequency of extreme weather events and the frequency of floods and droughts may all increase in Poland.

One of the features of the climate of Central Poland is frequent and irregular occurrence of rainless periods of various lengths which have a significant impact on vegetation. 
The trend of annual precipitation totals was not significant, while in the long-term course, all the analysed weather stations have shown periods with higher or lower annual precipitation totals in relation to the mean values. There are both periodic excesses and deficiencies of precipitation. Our analyses confirmed earlier studies by Ilnicki et al. (2012) and later by Bartczak et al. (2014).

The occurrence of dry and humid periods is anything but a new process. Such events have already occurred in the past; however, research and analyses carried out on various temporal and spatial scales indicate that nowadays they have become more frequent, their duration has lengthened, and their intensity has increased (e.g. Lorenc et al. 2008; Kaca et al. 2011), which was caused by a strong increase in air temperature. Lorenc et al. (2008) found that in Poland in the period 1951-1981 drought events occurred on average every 5 years, while in 1982-2008 they happened every 2 years. Alas, forecasts for the future are far from optimistic (IPCC 2018; WMO 2019). The threat of more frequent occurrence of extreme pluvial events of a more intense than the current nature may disturb the sustainable development of agricultural areas. Atmospheric drought events, especially in a longer time scale, bring the risk of hydrological, soil (agricultural) and, consequently, socio-economic droughts (Wilhite and Glantz 1985). The menacing result is a substantial reduction in the amount of water available to humans, animals and plants.

A long-term atmospheric drought causes measurable economic losses in agriculture (Łabędzki 2006; Kaca et al. 2011; Kundzewicz and Kozyra 2017). The very occurrence of such events, but in particular their frequency, duration, intensity and spatial scale, is difficult to predict (Eabędzki 2006). Still more difficult to foresee, perhaps even impossible, are the effects that such events may have in the future, hence the crucial role of research and analysis of historical droughts. Their proper quantification, as well as correct assessment and connection with a specific atmospheric state, i.e. the type of atmospheric circulation, may constitute a sound basis for further modelling studies.

Due to different methods of quantifying and describing dry periods adopted by various authors, a direct comparison of the obtained results proves problematic. Many studies on the occurrence of dry periods in Poland point at the latitudinal belt going across the central part of Poland, especially Greater Poland (the region adjacent to the study area from the west) and Kujawy, as the most threatened by droughts. Our results show a very high degree of compliance with the previously published data (e.g. Łabędzki and Bąk 2004; 2014; Lorenc et al. 2008; Bąk et al. 2012; Kędziora et al. 2014; Szyga-Pluta 2018).

The occurrence of the so-called circulation epochs (e.g. Sidorenkov and Orlov 2008; Degirmendžić and Kożuchowski 2018; Kononova and Lupo 2020) is one of the natural causes of the observed climate change. They are associated with increased or weaker appearance of certain types of atmospheric circulation, which favours the incidence of deficient or excessive precipitation. At the turn of the nineteenth and twentieth centuries, the zonal circulation (W) was prevailing; later, meridional forms developed, and after 1990 the zonal type came to dominate again (Degirmendžić and Kożuchowski 2018). In Central Europe, an increase in the intensity of air advection from the west at the end of the twentieth century was reported and confirmed (Ustrnul 2007), especially in the winter months (Bartoszek 2017b). Our research, also covering the early twenty-first century, indicated the persistence of a sound increase in the inflow of air masses from the west over Central Poland (a statistically significant upward trend was found for the $\mathrm{W}$ index).

In reference, literature analyses of the circulation conditioning of periods of deficit/excess of precipitation in Poland are sparse. In this study, we confirmed that the occurrence of drought events is favoured by anticyclonic circulation. Our research confirms the results obtained by, among others, Piotrowski (2010); Bąk and Maszewski (2012); ZiernickaWojtaszek (2012); Bartoszek (2014). Ustrnul and Czekierda $(2001,2009)$ and Łupikasza (2010) also analysed the impact of circulation on extreme precipitation throughout Poland. The highest daily totals of precipitation coincide with the inflow of air masses from the N-NE-E direction (Ustrnul and Czekierda 2001). Advection from this direction combined with cyclonic situations (mainly cyclonic trough and the centre of a low-pressure system) gives the highest probability of a heavy precipitation (Ustrnul and Czekierda 2001, 2009). The results of the research carried out in this study on Central Poland also indicate that the occurrence of extremely wet periods is caused by cyclonic circulation and the inflow of air from the north.

\section{Conclusion}

Precipitation plays a vital role in the global system controlling many environmental processes and conditioning human lives. Excessive precipitation, its scarcity or even non-existence heavily influence numerous fields of man's activity, e.g. agriculture.

The 1954-2018 mean annual total of precipitation in the study area (based on 10 stations) was $524 \mathrm{~mm}$. At that time, the trend of average yearly totals over Central Poland was not statistically significant. The differences in the spatial distribution of precipitation among the ten studied weather stations were caused, among others, by the topographic relief, the type of land cover and the direction of air mass advection. 
The Standardised Precipitation Index (SPI) provided the basis for assessing the periods of shortage and excess of humidity in terms of their duration and extent. In the study area, dry and wet periods (respectively SPI- $12 \leq-1.0$ and SPI-12 $\geq 1.0$ ) occurred with an average frequency of 28 and $27 \%$ during the analysed 65 years. In this timespan, the total number of dry periods ranged from 11 in Strzelno to 16 in Powidz and Sompolno. The number of wet periods ranged from 13 in Sobiesiernie and Powidz to 16 in Sompolno and Izbica Kujawska.

In their study spanning 65 years, the Authors presented air circulation with three indices: of western (W), southern (S) and cyclonic circulation (C). In the case of Central Poland, advection of air from the west prevails over that from the east, and so does the inflow of air from the south over that from the north. The frequency of anticyclonic situations is greater than that of cyclonic types.

The applied methodology allowed an objective comparison of precipitation deficits and excesses in time and space in Central Poland depending on atmospheric circulation. Dry periods occurred in the study area with a clear dominance of anticyclonic circulation, with the inflow of air from the north and with increased western circulation. On the other hand, the occurrence of wet periods over Central Poland was mainly influenced by the presence of cyclonic circulation, often with advection of air masses from the south and west.

The presented results, which sketch the portrait of the scarcity/excess of precipitation in central Poland, can be of invaluable importance for determining water shortages and water-related needs of crops and grasslands. It should be noted that within the study area, to maintain agricultural production at a high level, more intensive irrigation activities will be necessary.

We believe that the presented analyses that show the relationship and impact of the occurrence of a given type of atmospheric circulation on the incidence of extreme pluvial events can contribute to the development of mitigation pathways that can prepare and adapt such areas to the expected further climate change.

Acknowledgements The authors thank the Institute of Meteorology and Water Management - National Research Institute (IMGW-PIB) for kindly providing the Polish meteorological data.

Author contribution Study design: $\mathrm{AA}, \mathrm{AB}$; data collection: $\mathrm{AB}, \mathrm{RM}$, $\mathrm{AA}$; statistical analysis: AA, AB, RM, MK; result interpretation: AA, $\mathrm{AB}, \mathrm{RM}, \mathrm{MK}$; manuscript preparation: $\mathrm{AA}, \mathrm{AB}$; literature review: $\mathrm{AA}$, $\mathrm{AB}$.

Funding The research work of Andrzej Araźny was supported from the funds of the Nicolaus Copernicus University (grant no. 1665/2020/ IDUB.EF, Research University - Initiative of Excellence: the Emerging Field "Global Environmental Changes" and the "Climate Change Research Unit" at Nicolaus Copernicus University in Toruń).
Data availability Manuscript analyses meteorological data available on the Internet at https://danepubliczne.imgw.pl.

The data that support the findings of this study (among others the circulation indices W, S, and C, for Central Poland) are available from the corresponding author upon reasonable request.

Code availability Not applicable.

\section{Declarations}

Ethics approval and consent to participate Not applicable.

Consent for publication Not applicable.

Conflict of interest The authors declare no competing interests.

Open Access This article is licensed under a Creative Commons Attribution 4.0 International License, which permits use, sharing, adaptation, distribution and reproduction in any medium or format, as long as you give appropriate credit to the original author(s) and the source, provide a link to the Creative Commons licence, and indicate if changes were made. The images or other third party material in this article are included in the article's Creative Commons licence, unless indicated otherwise in a credit line to the material. If material is not included in the article's Creative Commons licence and your intended use is not permitted by statutory regulation or exceeds the permitted use, you will need to obtain permission directly from the copyright holder. To view a copy of this licence, visit http://creativecommons.org/licenses/by/4.0/.

\section{References}

Araźny A (2008) Bioclimatic conditions and their variability in the Norwegian Arctic for the period 1971-2000. Wyd Uni M Kopernika 215 pp (in Polish)

Araźny A (2019) Temporal and spatial variability of thermal and humidity stimuli in the Hornsund area (Svalbard). Polish Polar Res 40(1):29-53. https://doi.org/10.24425/ppr.2019.126346

Araźny A, Przybylak R, Wyszyński P, Wawrzyniak T, Nawrot A, Budzik T (2018) Spatial variations in air temperature and humidity over Hornsund ford (Spitsbergen) from 1 July 2014 to 30 June 2015. Geogr Ann Ser A Phys Geogr 100(1):27-43. https:// doi.org/10.1080/04353676.2017.1368832

Bartczak A (2007) Long-term variability of the river outflow from the Zgłowiączka basin. Prace Geogr IGiPZ PAN 209, 164 pp (in Polish)

Bartczak A, Glazik R, Tyszkowski S (2014) The application of BoxCox transformation to determine the Standardised Precipitation Index (SPI), the Standardised Discharge Index (SDI) and to identify drought events: case study in Eastern Kujawy (Central Poland). J Water Land Dev 22(7-9):3-15. https://doi.org/10. 2478/jwld-2014-0017

Bartczak A, Glazik R, Tyszkowski S (2013) Trends of yearly precipitation for Eastern Kujawy. Nauka Przyr Technol 7(1):1-18 (in Polish)

Bartoszek K (2014) Occurrence of atmospheric droughts in the Lublin area and atmospheric circulation conditions. Annales UMCS Sec E Agricultura 69(4):49-61 (in Polish)

Bartoszek K (2017) The main characteristics of atmospheric circulation over East-Central Europe from 1871 to 2010. Meteorol Atmos Phys 129(2):113-129. https://doi.org/10.1007/ s00703-016-0455-z 
Bartoszek K (2017) Temporal variability of atmospheric circulation indices over the Lublin region and their relationships with air temperature and precipitation. Prace Geogr 150:61-7. https:// doi.org/10.4467/20833113PG.17.017.732 (in Polish)

Bąk B, Łabędzki L (2002) Assessing drought severity with the relative precipitation index (RPI) and the standardized precipitation index (SPI). J Water Land Dev 6:89-105

Bąk B, Maszewski R (2012) Types of atmospheric circulation in the region Bydgoszcz-Torun during long-time meteorological drought in the years 1989-1998. Woda-Środow-Obszary Wiej 12(4):17-29 (in Polish)

Bąk B, Kejna M, Uscka-Kowalkowska J (2012) Meteorological droughts in the region of the station of Integrated Environmental Monitoring in Koniczynka (Chełmno Lakeland) in the years 1951-2010. Woda-Środow-Obszary Wiej 12(2):19-28 (in Polish)

Beranová R, Kyselý J (2018) Trends of precipitation characteristics in the Czech Republic over 1961-2012, their spatial patterns and links to temperature and the North Atlantic Oscillation. Int J Climatol 38:e596-e606. https://doi.org/10.1002/joc.5392

Boychenko S, Voloshchuk V, Movchan Y, Serdjuchenko N, Tkachenko V, Tyshchenko O, Savchenko S (2016) Features of climate change on Ukraine: scenarios, consequences for nature and agroecosystems. Proc National Aviation Univ 4:96-113 (in Ukraine)

Bordi I, Fraedrich K, Jm J, Sutera A (2004) Spatio-temporal variability of dry and wet periods in eastern China. Theor Appl Climatol 79:81-91

Bordi I, Fraedrich K, Petitta M, Sutera A (2007) Extreme value analysis of wet and dry periods in Sicily. Theor Appl Climatol 87:61-71

Box GEP, Cox DR (1964) An analysis of transformations. J R Stat Soc Series B 26(2):211-252

Box GEP, Cox DR (1982) An analysis of transformations Revisited. Rebutted J R Stat Soc 77(377):209-210

Brázdil R, Dobrovolný P, Trnka M, Kotyza O, Řezníčková L, Valášek H, Zahradníček P, Štěpánek P (2013) Droughts in the Czech Lands, 1090-2012 AD. Clim past 9:1985-2002. https://doi.org/ 10.5194/cp-9-1985-2013

Brázdil R, Dobrovolný P, Trnka M, Büntgen U, Řezníčková L, Kotyza O, Valášek H, Štěpánek P (2016) Documentary and instrumentalbased drought indices for the Czech Lands back to AD 1501. Clim Res 70:103-117. https://doi.org/10.3354/cr01380

Brázdil R, Kiss A, Luterbacher J, Nash DJ, Řezníčková L (2018) Documentary data and the study of past droughts: a global state of the art. Clim past 14:1915-1960. https://doi.org/10.5194/ cp-14-1915-2018

Brykała D (2009) Spatial and time differentiation of river discharge within the Skrwa Lewa river basin. Prace Geogr 221, 142 pp (in Polish)

Czarnecka M, Nidzgorska-Lencewicz J (2012) Multiannual variability of seasonal precipitation in Poland. Woda-Środow-Obszary Wiej 12(2): 45-60 (in Polish)

Degirmendžić J, Kożuchowski K (2018) Circulation epochs based on the Vangengeim-Girs large scale patterns (1891-2010). Acta Univ Lodz Folia Geogr Phys 17: 7-13. https://doi.org/10.18778/ 1427-9711.17.01

Degirmendžić J, Kożuchowski K, Żmudzka E (2004) Changes of air temperature and precipitation in Poland in the period 1951-2000 and their relationship to atmospheric circulation. Int J Climatol 24(3):291-310. https://doi.org/10.1002/joc.1010

Falarz M (2007) Snow cover variability in Poland in relation to the macro- and mesoscale atmospheric circulation in the twentieth century. Int J Climatol 27(15):2069-2081. https://doi.org/10. 1002/joc. 1505

Hänsel S, Petzold S, Matschullat J (2009) Precipitation trend analysis for Central Eastern Germany 1851-2006. In: Střelcová K,
Škvarenina J, Blaženec M (eds) Bioclimatology and natural hazards. Springer, pp 29-38

Hellwig Z (1967) A model of statistical prediction by means of the method of harmonical weights. Przegl Statyst XIV 2:133-153 (in Polish)

Hess P, Brezowsky H (1969) Katalog der Grosswetterlagen Europas. Bericht des Deutschen Wetterdienstes. Offenbach am Main 113, $70 \mathrm{pp}$

Hess P, Brezowsky H (1977) Katalog der Grosswetterlagen Europas (1881-1976). 3. Verbesserte und ergänzte Auflage, Berichte des Deutschen Wetterdienstes 113, 68 pp

Hirsch RM, Slack JR, Smith RA (1982) Techniques of trend analysis for monthly water quality data. Water Resour Res 18(1):107-121

Hurrell JW (1996) Influence of variations in extratropical wintertime teleconnections on northern hemisphere temperature. Geophys Res Lett 23:665-668

IPCC (2013) Climate change 2013: the physical science basis. Contribution of Working Group I to the Fifth Assessment Report of the Intergovernmental Panel on Climate Change. Stocker TF, Qin D, Plattner G-K, Tignor M, Allen SK, Boschung J, Nauels A, Xia Y, Bex V, Midgley PM (eds) Cambridge Univ Press, Cambridge, $1535 \mathrm{pp}$

IPCC (2018) Summary for policymakers, In: Global warming of $1.5^{\circ} \mathrm{C}$. An IPCC Special Report on the impacts of global warming of $1.5^{\circ} \mathrm{C}$ above pre-industrial levels and related global greenhouse gas emission pathways, in the context of strengthening the global response to the threat of climate change, sustainable development, and efforts to eradicate poverty. MassonDelmotte V, Zhai P, Pörtner H.-O, Roberts D, Skea J, Shukla PR, Pirani A, Moufouma-Okia W, Péan C, Pidcock R, Connors S, Matthews JBR, Chen Y, Zhou X, Gomis MI, Lonnoy E, Maycock T, Tignor M, Waterfield T (eds) Electronic copies from the IPCC website www.ipcc.ch

Ilnicki P, Farat R, Górecki K, Lewandowski P (2012) Myth of the steppe forming process in the Wielkopolska region from the viewpoint of long investigations of water circulation. Wyd Uniw Przyr Poznań, 400 pp (in Polish)

IMGW (2020) Drought. http://posucha.imgw.pl. Accessed 12 Sept 2020

Isaksen K, Nordli Ø, Førland EJ, Łupikasza E, Eastwood S, Niedźwiedź T (2016) Recent warming on Spitsbergen - influence of atmospheric circulation and sea ice cover. J Geophys Res Atmos 121:11913-11931. https://doi.org/10.1002/2016J D025606

Jacobeit J, Jönsson P, Bärring L, Beck C, Ekström M (2001) Zonal indices for Europe 1780-1995 and running correlations with temperature. Clim Change 48:219-241

Kaca E, Łabędzki L, Lubbe I (2011) Agricultural water management in view of extreme weather phenomena. Postępy Nauk Rol 1:37-49 (in Polish)

Kędziora A, Kępińska-Kasprzak M, Kowalczak P, Kundzewicz ZW, Miler AT, Pierzgalski E, Tokarczyk T (2014) Risks Resulting from Water Shortages Nauka 1:149-172 (in Polish)

Kot MS, Jakubowski J, Sokołowski A (2011) Statistics. Difin, Warszawa, 526 pp (in Polish)

Kundzewicz ZW, Kozyra J (2017) The impact of climate change on agriculture in Poland. In: Kundzewicz ZW, Hov Ø, Okruszko T (eds) Zmiany klimatu i ich wpływ na wybrane sektory w Polsce, Poznań, pp 168-181 (in Polish)

Kowalczak P, Farat R, Kępińska-Kasprzak M, Kuźnicka M, Mager P (1997) The hierarchy of spatial needs of small-scale water retention. Seria Gosp Wodna Ochrona Wód 19, IMGW Warszawa (in Polish)

Kożuchowski K (1993) Variations in hemispheric zonal index since 1899 and its relationship with air temperature. Int J Climatol 13:853-864. https://doi.org/10.1002/joc.3370130804 
Kononova NK, Lupo AR (2020) Changes in the dynamics of the Northern Hemisphere atmospheric circulation and the relationship to surface temperature in the 20th and 21st centuries. Atmosphere 11(3):255. https://doi.org/10.3390/atmos11030255

Kutiel H, Maheras P, Guika S (1996) Circulation indices over the Mediterranean and Europe and their relationship with rainfall conditions across the Mediterranean. Theor Appl Climatol 54(3-4):125-138

Lamb HH (1972) British Isles weather types and a register of the daily sequences of circulation patterns 1861-1971. Geophys Memoirs 116 , London, $85 \mathrm{pp}$

Lambor J (1954) Steppe-forming process in Central Poland. Prace PIHM, Warszawa (in Polish)

Lityński J (1969) Numerical classification of circulation and weather types in Poland. Prace PIHM 97:3-15 (in Polish)

Livada I, Assimakopoulos VD (2007) Spatial and temporal analysis of drought in Greece using the Standardized Precipitation Index (SPI). Theor Appl Climatol 89:143-153. https://doi.org/10.1007/ s00704-005-0227-z

Lloyd-Hughes B, Saunders MA (2002) A drought climatology for Europe. Int J Climatol 22(13):1571-1592. https://doi.org/10. $1002 /$ joc. 846

Lorenc H, Mierkiewicz M, Sasim M (2008) Drought in Poland from special regard year 2006 (history, causes, intensity, range, results, conclusions). Wiad IMGW II(1-2):3-32 (in Polish)

Łabędzki L (2006) Agricultural droughts. An outline of problems and methods of monitoring and classification. Woda-ŚrodowObszary-Wiej, Rozpr naukowe i monografie 17, Wyd IMUZ, Falenty, 107 pp (in Polish)

Łabędzki L (2007) Estimation of local drought frequency in central Poland using the standardized precipitation index SPI. Irrig Drain 56(1):67-77

Łabędzki L (2008) Estimation of different duration drought frequency using the standardized precipitation index SPI. Zesz Prob Pos Nauk Rol 526:105-112 (in Polish)

Łabędzki L, Bąk B (2004) Differentiation of the atmospheric drought index SPI in the vegetation period in Poland. Woda-ŚrodowObszary Wiej 4(2a):111-122 (in Polish)

Łabędzki L, Bąk B (2014) Meteorological and agricultural drought indices used in drought monitoring in Poland: a review. Meteo Hydrol Water Manag 2(2):3-13

Łupikasza E (2010) Relationships between occurrence of high precipitation and atmospheric circulation in Poland using different classifications of circulation types. Phys Chem Earth $\mathrm{a} / \mathrm{b} / \mathrm{c}$ 35(9):448-455. https://doi.org/10.1016/j.pce.2009.11.012

Łupikasza E, Niedźwiedź T (2019) The influence of mesoscale atmospheric circulation on Spitsbergen air temperature in periods of Arctic warming and cooling. J Geophys Res Atmos 124:52335250. https://doi.org/10.1029/2018JD029443

Mckee TB, Doesken NJ, Kleist J (1993) The relationship of drought frequency and duration to time scales. In: Proc. 8th Conference Appl Clim, Anaheim, CA American Meteorol Society, pp 179-184

Murray R, Lewis RP (1966) Some aspects of the synoptic climatology of the British Isles as measured by simple indices. Meteorol Mag 95:193-203

National Drought Mitigation Centre (2020) https://drought.unl.edu/. Accessed 10 Dec 2020

Niedźwiedź T (1981) Synoptic situations and their influence on spatial differentiation of selected climate elements in the upper Vistula basin. Rozpr Hab UJ 58, 165 pp (in Polish)

Niedźwiedź T (2000) Variability of the atmospheric circulation above Central Europe in the light of selected indices. Zesz Nauk UJ, Prace Geogr 107:379-389
Niedźwiedź T (2001) Variability of atmospheric circulation above Spitsbergen in the second half of 20th Century. Probl Klimat Polar 11:7-26 (in Polish)

Niedźwiedź T (2013) The atmospheric circulation. In: Styszyńska A (ed) Marsz AA. Climate and climate change at Hornsund, Svalbard, Gdynia Maritime Univ, Gdynia, pp 57-74

Niedźwiedź T (2013) Influence of atmospheric circulation on the air temperature at Hornsund. In: Styszyńska A (ed) Marsz AA. Climate and climate change at Hornsund, Svalbard, Gdynia Maritime Univ, Gdynia, pp 172-177

Niedźwiedź T (2017) Calendar of circulation types for Southern Poland. Computer file available at the Department of Climatology, Univ Silesia. http://klimat.wnoz.us.edu.pl/. Accessed 11 Mar 2020

Niedźwiedź T, Twardosz R, Walanus A (2009) Long-term variability of precipitation series in east central Europe in relation to circulation patterns. Theor Appl Climatol 98(3-4):337-350. https://doi org/10.1007/s00704-009-0122-0

Niedźwiedź T, Łupikasza E (2015) Dynamics of circulation indices over Spitsbergen. Probl Klimat Polar 25:153-167 (in Polish)

Niedźwiedź T, Łupikasza E (2019) Atmospheric circulation in the investigations of the Polish climatologists. Przegl Geofiz 1-2:107-166 (in Polish)

Nowosad M (2011) Variability of the meridional circulation index over Poland according to the Lityński classification formula. Prace i Studia Geogr 47:41-48

Piotrowski P (2010) Circulation-related conditioning of spring droughts in Poland In: Bednorz E (ed) Klimat Polski na tle klimatu Europy. Warunki termiczne i opadowe, Bogucki Wyd Nauk, Poznań: 147-158 (in Polish)

Pińskwar I, Choryński A, Graczyk D, Kundzewicz ZW (2019) Observed changes in precipitation totals in Poland. Geografie 124: 237-264. https://doi.org/10.37040/geografie20191240302 37

Przybylak R, Maszewski R (2009) Atmospheric circulation variability in the Bydgosko-Toruński Region in the period 1881-2005. Acta Agrophys 14(2):427-447 (in Polish)

Przybylak R, Oliński P, Koprowski M, Filipiak J, Pospieszyńska A, Chorążyczewski W, Puchałka R, Dąbrowski PH (2020) Droughts in the area of Poland in recent centuries in the light of multiproxy data. Clim past 16(2):627-661. https://doi.org/10.5194/ cp-16-627-2020

Sidorenkov NS, Orlov IA (2008) Atmospheric circulation epochs and climate changes. Russian Meteorol Hydrol 33(9):553-559

Szwed M (2019) Variability of precipitation in Poland under climate change. Theor Appl Climatol 135:1003-1015. https://doi.org/10. 1007/s00704-018-2408-6

Szyga-Pluta K (2018) Variability of drought occurrence during growing season in Poland in years 1966-2015. Przegl Geofiz LXIII 1-2:51-67 (in Polish)

Tomingas O (2002) Relationship between atmospheric circulation indices and climate variability in Estonia. Boreal Environ Res 7:463-469

Twardosz R (2009) Analysis of hourly precipitation characteristics in Kraków, southern Poland, using a classification of circulation types. Hydrol Res 40(6):553-563. https://doi.org/10.2166/nh. 2009.056

Twardosz R (2010) An analysis of diurnal variations of heavy hourly precipitation in Kraków using a classification of circulation types over southern Poland. Phys Chem Earth 35:456-461. https://doi. org/10.1016/j.pce.2009.11.003

Twardosz R, Niedźwiedź T (2001) Influence of synoptic situations on the precipitation in Kraków (Poland). Int J Climatol 21:467-481. https://doi.org/10.1002/joc.620 
Twardosz R, Niedźwiedź T, Łupikasza E (2011) The influence of atmospheric circulation on the type of precipitation (Krakow, southern Poland). Theor Appl Climatol 104:233-250. https:// doi.org/10.1007/s00704-010-0340-5

Ustrnul Z (1997) Variability of atmospheric circulation in the northern hemisphere in the 20th century. Mat Bad IMGW, Seria Meteorol 27, Warszawa, 208 pp (in Polish)

Ustrnul Z (2007) Variability of the westerly circulation index over Europe in the 20th century. In: Piotrowicz K, Twardosz R (eds) Wahania klimatu w różnych skalach przestrzennych i czasowych, Kraków: 55-63 (in Polish)

Ustrnul Z, Czekierda D (2001) Circulation background of the atmospheric precipitation in Central Europe (based on the Polish example). Meteorol Zeit 10(2):103-111. https://doi.org/10.1127/09412948/2001/0010-0103

Ustrnul Z, Czekierda D (2009) Atlas of extreme meteorological phenomena and synoptic situations in Poland. IMGW, Warszawa (in Polish)

Wibig J (1999) Precipitation in Europe in reaction to circulation patterns at the $500 \mathrm{hPa}$ level. Int J Climatol 19(3):253-269. https:// doi.org/10.1002/(SICI) 1097-0088(19990315)19:3<253::AIDJOC366>3.0.CO;2-0

Wibig J (2001) The influence of atmospheric circulation on spatial distribution of temperature and precipitation anomalies in Europe. Rozpr Hab Uniw Łódz, Łódź, 208 pp (in Polish)

Wibig J (2009) The variability of daily precipitation totals in Poland. Geogr Pol 82(1):21-32

Wibig J, Piotrowski P (2018) Impact of the air temperature and atmospheric circulation on extreme precipitation in Poland. Int J Climatol 38:4533-4549. https://doi.org/10.1002/joc.5685

Wilhite DA, Glantz MH (1985) Understanding the drought phenomenon: the role of definition. Water Int 10(3):111-120
WMO (2012) Standardized Precipitation Index (Svoboda M, Hayes M, and Wood D). User guide. WMO-1090, Geneva, 16 pp

WMO (2019) Statement on the state of the global climate in 2018. WMO-No. 1233, 39 pp

Woś A (2010) Climate of Poland in the second half of the 20th century. Wyd Nauk Uniw A. Mickiewicza, Poznań, 489 pp (in Polish)

Wójcik G, Marciniak K (1993) Precipitation in the area of the lower Vistula in 1951-1980. In: Churski Z (ed) Uwarunkowania przyrodnicze i społeczno-ekonomiczne zagospodarowania dolnej Wisły, Toruń: 107-121 (in Polish)

Ziernicka-Wojtaszek A (2012) Circulation-related conditioning of agricultural droughts in Podkarpackie Voivodeship. Infrastrukt Ekol Ter Wiej 2:153-162 (in Polish)

Ziernicka-Wojtaszek A, Kopcińska J (2020) Variation in atmospheric precipitation in Poland in the years 2001-2018. Atmosphere 11(8):794. https://doi.org/10.3390/atmos11080794

Zhang Q, Cy Xu, Zhang Z (2009) Observed changes of drought/wetness episodes in the Pearl River basin, China, using the standardized precipitation index and aridity index. Theor Appl Climatol 98:89-99. https://doi.org/10.1007/s00704-008-0095-4

Żmudzka E (2002) On precipitation variability in lowland Poland in the second half of the 20th century. Wiad IMGW 25(46), 4: 23-38 (in Polish)

Publisher's note Springer Nature remains neutral with regard to jurisdictional claims in published maps and institutional affiliations. 